\title{
IMPLEMENTATION REQUIREMENTS OF STATE MARKETING IN TOURIST TERRITORIES
}

\author{
ALMAGUL NURGALIYEVA \\ Kokshe academy, Kazakhstan
}

\section{ABSTRACT}

The present article is dedicated to the issue of implementation of State Marketing requirements in tourist territories, which is very important nowadays. It also reflects the main issues sensible in this sphere.

\section{JEL CLASSIFICATION \& KEYWORDS}

- M00 - Marketing - Tourism

\section{INTRODUCTION}

One of the powerful instruments in the system of politicallegal influence on tourism sphere in the Republic of Kazakhstan is the privatization process of enterprise in tourism industry, development of various forms of property. For instance, local legislation, regulatory framework in natural environment protection, fiscal, customs, labor regulation sphere, laws and rules on safety, consumers sphere are the main factors. Tourism policy of territory administration exerts a direct influence, i.e. a goal oriented impact on tourism development and its foundation by means of influence on important peculiarities to the given activity [1].

Tourism market management predicts more or less participation of the state. Such participation is usually expressed in macroeconomic equilibrium progress and security and also in micro market regulations (individual and local tourism products market) which is relative to the scientific term "State marketing".

\section{State marketing}

Decentralized state marketing is necessary for present mixed unique marketing subject, and the state marketing comes to the fore as the partner of non-state sector.

First of all, state marketing practice results from the fact that at this time it is already unconceivable to hold a state policy without taking care of people's well being and ways of corresponding services distribution. Thus, marketing approach practice in frame of definition and implementation of state policy is consisted in detailed diagnosis of necessities, demand, expectance by means of marketing methods (for example: segmentation) [2].

Decentralized state marketing is the way of market management, impact on supply-and-demand situation on purpose of making a special market trends in the interests of state.

It is possible to regulate the situation in tourist market by three ways. The first way is to provoke changes in demand by means of making a corresponding supply.

The second way is the script of reversed order. Here the demand carries out the role of means and changes of product proposal output is perceived as the result of tempo changes and demand trajectory were undertaken by state administration bodies.

For instance, one may achieve direct changes of tourist demand by means of changing the extent of total cash income through the release of extra money cycle or meaningful constraints of money (method offered by John Maynard Keynes); employee restructuring and free time of consumers' tourist product.
The third way is the simultaneous impact on supply and demand in tourist market by way of achieving state goals.

State tourist marketing must be carried out in modern conditions as per the third way with simultaneous impact on supply and demand for tourist market in national interests.

One of the most important spheres of using tourist marketing technologies in national level is the research on purpose of improving tourist potential of the state and its territory, development of external and internal tourism [3]. The main tasks solved by marketing research of tourist market are: tourism share analysis in gross domestic product, measures needed for increasing incomes from tourism sphere, identifying strategic markets outlet and population groups, instrument implementation and promotion of competitive tourist products in internal and foreign markets. Standard marketing research of tourist market organized in national level which represents information gathering on purpose of solving the following issues:

- To learn supply structures at tourist market,

- to identify orders of priority in tourism sphere for economic system of the state,

- to hold analysis of internal and external tourist branches,

- to identify vital issues and main problems of tourist sphere of the state,

- to find out competitive advantages and the blind sides of national tourist product

- to identify tourist potential of the state and strategic markets and population groups,

- to define maximal efficient position of the state at world tourist market,

- to determine prior arrangements for tourism development in the country by way of simultaneous impact on the main principals (supply and demand) at tourist market and also distinguish more efficient instruments of the impact.

Summing up macroeconomic research of tourist market, the strategy of tourism sphere at the internal and external market is developed:

There are identified strategic external markets in tourism sphere; target groups of foreign tourists; main criteria of differentiating tourist product and also promotion of national tourist product representing the country in foreign market [4]

Accreditated tourist firms and their association, specialized state bodies including foreign tourist representation and authorized foreign tourist firms at target markets can be performed. The main purpose of tourist macro marketing subjects is the foundation, maintenance and changes of ideas, intentions and behavior of consumers' subjects.

To implement a target orientation, tourist marketing develops measures which support the following:

- Foundation and improvement of state image, its status, business and social competitiveness,

- extension of territories and its subjects to implement international and internal tourist programs, 
- attraction of foreign tourist business that reduces formation method oriented to the target group of tourist product and its promotion at target market [5].

\section{Conclusion}

Thus, the main purpose of state marketing at tourist market in Kazakhstan must be formation and development of public recognition support of positive image as tourist trend.

Tourist image of the state or territory is the complex of presentations about tendencies of travel which is formed and registered in foreign public consciousness due to primary acquaintance.

Firstly, presentations should contain instructions at unique tourist re-source and industry; secondly, to idealize the territory as the place for recreation; thirdly, to be more dynamic in order to adapt for requirements of current situation and conjuncture of international tourist market.

\section{REFERENCES}

1. E.I. Bogdanov., O.N. Kostryukova., V.P. Orlovskaya., P.M. Fenin., Planning tourism at the enterprise//Business press. - 2003. - p 109 2. Zh.P. Blandinyer. Changes of fundamental industrial and social paradigm // Transformation of social sphere in Europe. - M.: Case $-2003-\mathrm{p} 75$.

3. New marketing technologies. Methods of forming genuine ideas by Philip Kotler, Fernando Trias de Bez, Edition: Neva - 2004.

4. http://www.marketing.kharkov.ua/

5. A.P. Pankrukhin Territory marketing // Advertiser: thery and practice - 2002. - \#1. p. 67-67. 